\title{
Chemical Characterization of Pineapple Leaf Residue Chars generated by Controlled Combustion and by open burning
}

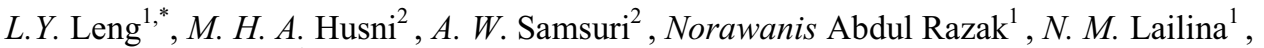 \\ and Ras Izzati Ismail ${ }^{1}$ \\ ${ }^{1}$ Faculty of Engineering Technology, Universiti Malaysia Perlis (UniMAP), Campus of UniCITI \\ Alam Sungai Chuchuh, Padang Besar, 02100 Perlis, Malaysia. \\ ${ }^{2}$ Department of Land Management, Faculty of Agriculture, Universiti Putra Malaysia, 43400 Serdang \\ Selangor, Malaysia.
}

\begin{abstract}
This study was undertaken to compare the chemical characteristics of pineapple leave residues (PLRs) char generated by controlled combustion and by open burning. The properties of char generated by control combustion (CC) and open burning (OB) varied, due to differences in the production process. The total N, K and surface area of the char generated by $\mathrm{CC}$ were significantly higher than the $\mathrm{OB}$. The results indicate that the $\mathrm{CC}$ process was better to be applied as a soil amendment than was the $\mathrm{OB}$ process.
\end{abstract}

\section{Introduction}

In Malaysia, nearly $70 \%$ of the pineapple crop is planted on peat [1]. Though relatively small compared to oil palm and rubber, the pineapple industry plays an important role in the country's socio-economic development of Malaysia.

Abundant of leave residues are produced in the field and open burning is commonly practiced to manage the plant residues in pineapple plantation. As a result, large amount of carbon $(\mathrm{C})$, nitrogen $(\mathrm{N})$ and greenhouse gaseous are emitted to the atmosphere from burning. Alternative way to manage the residues is converting the residues to char and applied as a soil amendment. The char is composed of large amount of stable aromatic carbon and sequester $\mathrm{C}$ if used as a soil amendment.

Furthermore, previous studies found out biochar is a good soil amendment as it can increase soil water holding capacity of sandy soil [2] and increase crop yields [3]. Field burning not only convert the biomass into volatile organic compounds, inorganic gas oxides but also chars. Approximate 4 to $6 \%$ of chars is produced during the open burning [4,5]. The application of biochar to the soil has been proposed to increase the stable nutrient pool. Control combustion is suggested a better way to retain the nutrient in the char rather than

*Corresponding author: yllee@unimap.edu.my 
open burning. However, there is lack of information of the comparisons of chemical properties of pineapple leaf residue (PLR) chars from control combustion and open burning processes. This study was carried out to determine the chemical characteristics of PLR, chars generated from control combustion and field burning, to compare the characteristics of chars generated by control combustion and open burning.

\section{Materials and methods}

There were two types of chars being generated under different combustion conditions. The chemical characteristics of the chars varied under different processing and thus were analysed for $\mathrm{pH}$, electrical conductivity (EC), macronutrient contents, cation exchange capacity (CEC) and BET surface area.

\subsection{Open burning-generated char}

The study site was the Peninsula Pineapple Plantation, Johor, Malaysia. Pineapple leaf samples were collected and air-dried for three months prior to char production under control combustion (CC). The chars were collected after the open burning (OB) conducted in a 6 ha area of the plantation [4]. The char samples from the open burning process were oven-dried, ground, sieved to pass a $2 \mathrm{~mm}$ sieve and kept in air-tight plastic containers prior to chemical analysis.

\subsection{Control combustion-generated char}

The pineapple leave residues (PLRs) were converted into chars in the laboratory by taking $90 \mathrm{~g}$ of air-dried leaf samples and combusted them for 3 hours at $340^{\circ} \mathrm{C}$ [6] in a Carbolite ELF 11/23 type furnace. The char samples from CC were processed similarly to the char samples from OB prior to chemical analysis.

\section{$2.3 \mathrm{pH}$ and electrical conductivity (EC) of chars}

The $\mathrm{pH}$ and $\mathrm{EC}$ content of leave and char samples were analyzed using a $\mathrm{pH}$ meter and a conductivity meter (Radiometer Analytical, ION check 30$)$ by mixing a 1:10 (v/v) ratio of sample to water.

\subsection{Total $\mathrm{C}$ and $\mathrm{N}$ analysis}

Total nitrogen $(\mathrm{N})$ was determined using a micro-Kjeldahl method [7] while Total $\mathrm{C}(\%)$ was determined by a dry combustion method using a CT analyzer (LECO CR-412, Michigan, USA).

\subsection{Total macronutrient analysis}

Dry ashing was adopted for the determination of phosphorus $(\mathrm{P})$, potassium $(\mathrm{K})$, calcium (Ca) and magnesium $(\mathrm{Mg})$. 


\subsection{Available P of Char analysis}

Available $\mathrm{P}$ in the char samples was determined by Olsen method [8]. One $\mathrm{g}$ of char generated by $\mathrm{CC}$ and $\mathrm{OB}$ processes was weighed into the plastic vial. Then, $20 \mathrm{~mL}$ of the extracting solution was added and shaked for 30 minutes. Lastly, the extract was filtered using Whatman no.2 filter paper and the P in solution was determined using Auto Analyzer (AA).

\subsection{Available $\mathrm{K}, \mathrm{Ca}, \mathrm{Mg}$ and cation exchange capacity (CEC) of char determination}

Prior to analysis, char samples were washed 3 times with deionized water to remove soluble salts. Ammonium acetate shaking methods at $\mathrm{pH} 7$ [9] was used to determine CEC of char samples. About $10 \mathrm{~g}$ of samples was weighed into centrifuge bottle, and added with $1 \mathrm{M}$ ammonium acetate solution. Afterwards, it was shaken for 30 minutes at $180 \mathrm{rpm}$ by using reciprocal shaker. After shaking, the bottle was centrifuged at $2500 \mathrm{rpm}$ for 10 minutes. The supernatant was later filtered using Whatman no. 2 filter paper, $\mathrm{K}, \mathrm{Ca}$ and $\mathrm{Mg}$ in the supernatant was determined using AA and atomic absorption spectrophotometer (AAS). To remove free ammonium ion from the char, $100 \mathrm{~mL}$ of ethanol was added into the centrifuge bottle. Afterwards, it was shaken for 30 minutes, centrifuged, and the supernatant was discarded. This step was repeated for 2 more times. A $100 \mathrm{~mL}$ of $0.1 \mathrm{~N}$ potassium sulfate was added in the centrifuge bottle and shake for 30 minutes, centrifuged, then supernatant was filtered and send to AA for CEC determination.

\subsection{BET surface area}

The multipoint Brunauer, Emmett and Teller (BET) was used to measure surface area of char samples. Nitrogen adsorption technique at $77 \mathrm{~K}$ with Automated Gas Sorption Analyzer (Autosorb-1, Quantachrome instruments version 2.01) was used for this purpose. The specific surface area was determined by application of BET analysis software available with the instrument.

\subsection{Statistical analysis}

An independent t-test was used to detect significant differences between chemical value of the char produced from the CC treatment and from the OB process. Statistical Analysis System (SAS) software version 9.1 was used for the statistical analysis.

\section{Results and discussion}

The chemical characteristic of the chars generated under $\mathrm{CC}$ and $\mathrm{OB}$ conditions were analysed and the two different processes will be compared for better quality in term of the nutrient content. 


\subsection{Macronutrient, $\mathrm{pH}$ and EC of char}

The properties of char generated by $\mathrm{CC}$ and $\mathrm{OB}$ varied, due to differences in the production process. The properties of the char are shown in Table 1.0. Both CC and OB combustion processes show high $\mathrm{pH}(>9)$ and salinity $(>7 \mathrm{mS} / \mathrm{cm})$ in the char, and the high $\mathrm{pH}$ and salinity indicate the chars are good soil liming materials. Mineral ash produced during high heating rate in $\mathrm{OB}$ process resulted a significant higher $\mathrm{pH}$ in the char generated by $\mathrm{OB}$. A significantly higher level of EC found for the CC process suggests that a higher content of metal salts was retained in the laboratory-produced char, probably due to slower heating rates [4].

Total C content under CC conditions (53.30\%) was higher than OB conditions (42.19\%). A controlled temperature and slow heating rates for the $\mathrm{CC}$ production condensed the $\mathrm{C}$ of $\mathrm{PLR}$, thereby increasing the total $\mathrm{C}$ from the $\mathrm{CC}$ process. In contrast, high and uncontrolled temperatures during the $\mathrm{OB}$ in the field, would have produced a high level of mineral ash and resulted in more $\mathrm{C}$ weight loss [4]. This finding agrees with work of [10], who also found that controlled combustion could further increase the $\mathrm{C}$ content of the char that was produced.

The total $\mathrm{N}$ under $\mathrm{CC}$ conditions $(2.60 \%)$ was significantly higher than under $\mathrm{OB}$ conditions (1.77\%) (Table 1). This difference could be attributed to the volatilization of $\mathrm{N}$ compounds during open burning at high temperatures. However, $\mathrm{N}$ was not volatilized but underwent condensation in the $\mathrm{CC}$ process during the controlled combustion.

Table 1. $\mathrm{pH}$, electrical conductivity (EC), total $\mathrm{C}$, total $\mathrm{N}$ and $\mathrm{C} / \mathrm{N}$ ratio of chars produced by controlled combustion $(\mathrm{CC})$ and open burning $(\mathrm{OB})$

\begin{tabular}{|c|c|c|}
\hline Parameter & CC & OB \\
\hline $\mathrm{pH}$ & $9.45^{\mathrm{b}}$ & $9.65^{\mathrm{a}}$ \\
\hline $\mathrm{EC}(\mathrm{mS} / \mathrm{cm})$ & $12.27^{\mathrm{a}} \pm 0.11$ & $7.87^{\mathrm{b}} \pm 0.87$ \\
\hline Total C (\%) & $53.30^{\mathrm{a}} \pm 0.70$ & $42.19^{\mathrm{b}} \pm 0.37$ \\
\hline Total N (\%) & $2.6^{\mathrm{a}} \pm 0.10$ & $1.77^{\mathrm{b}} \pm 0.03$ \\
\hline
\end{tabular}

\subsection{Total and available $\mathrm{P}, \mathrm{K}, \mathrm{Ca}, \mathrm{Mg}$ concentrations and CEC of char}

Total $\mathrm{P}, \mathrm{Ca}, \mathrm{Mg}$ and the relevant exchangeable nutrients as well under $\mathrm{OB}$ conditions were significantly higher than under CC conditions (Table 2). This difference could be attributed to parts of the PLRs were converted into ash during field burning at high heating rates and temperature and the presence of minerals in the ash residues, thereby increased the concentration of total $\mathrm{P}, \mathrm{Ca}$ and $\mathrm{Mg}$ under $\mathrm{CF}$ conditions.

While the $\mathrm{K}$ concentration under $\mathrm{OB}$ conditions were significantly lower than under $\mathrm{CC}$ conditions, suggesting that $\mathrm{K}$ ions are highly mobile and vaporized at relatively high temperature during open burning in field [11]. The CEC of the char produced by both CC and $\mathrm{OB}$ processes was not significantly different and the values are consistent with the CEC of carbonized rice husk reported in literature [12]. The CEC of the chars tested in this study $(15.97-18.80 \mathrm{cmol}(+) / \mathrm{kg})$ were greater by at least half than the CEC of Ultisols and Oxisols $(3-7 \mathrm{cmol}(+) / \mathrm{kg})$ in tropical area [13], except Histosols. The surface area of char 
made under OB process was found to be lower than under CC process (Table 2.0) suggests that the cell structure of char generated by OB was destroyed by rapid devolatilization rate of the PLRs burned at high heating rates. Higher surface area of char generated by CC enable it to adsorb and retain more nutrients.

Table 2: Available $\mathrm{P}$, exchangeable $\mathrm{K}, \mathrm{Ca}, \mathrm{Mg}, \mathrm{CEC}$ and surface area of pineapple leaf char produced by $\mathrm{CC}$ and $\mathrm{OB}$ processes

\begin{tabular}{|c|c|c|}
\hline Parameter & CC & OB \\
\hline Total P (\%) & $0.32^{\mathrm{b}}$ & $0.37^{\mathrm{a}}$ \\
\hline Total K (\%) & $8.29^{\mathrm{a}} \pm 0.06$ & $5.17^{\mathrm{b}} \pm 0.21$ \\
\hline Total Ca (\%) & $0.05^{\mathrm{b}}$ & $0.93^{\mathrm{a}} \pm 0.02$ \\
\hline Total Mg (\%) & $0.35^{\mathrm{b}} \pm 0.01$ & $0.75^{\mathrm{a}} \pm 0.02$ \\
\hline Exch. $\mathrm{K}(\mathrm{cmol}(+) / \mathrm{kg})$ & $28.73^{\mathrm{a}} \pm 0.84$ & $10.84^{\mathrm{b}} \pm 0.17$ \\
\hline Exch. Ca $(\mathrm{cmol}(+) / \mathrm{kg})$ & $1.71^{\mathrm{b}} \pm 0.02$ & $11.69^{\mathrm{a}} \pm 0.05$ \\
\hline Exch. $\mathrm{Mg}(\mathrm{cmol}(+) / \mathrm{kg})$ & $7.02^{\mathrm{b}} \pm 0.28$ & $15.88^{\mathrm{a}} \pm 0.39$ \\
\hline CEC $(\mathrm{cmol}(+) / \mathrm{kg})$ & $18.8^{\mathrm{a}} \pm 0.81$ & $15.97^{\mathrm{a}} \pm 0.86$ \\
\hline BET surface $\mathrm{area}\left(\mathrm{m}^{2} / \mathrm{g}\right)$ & 5.46 & 2.08 \\
\hline
\end{tabular}

\section{Summary}

The concentrations of total $\mathrm{C}, \mathrm{N}$ and macronutrient contents were condensed and increased during conversion of biomass into chars. The chemical properties of PLRs chars varied depending on the combustion conditions. Higher concentrations of total N, K and surface area in the chars generated by $\mathrm{CC}$ process suggests the chars under $\mathrm{CC}$ process can be applied as a better soil amendment than OB process. However, the effect of PLRs chars on soil nutrient and plant growth should be examined in future research.

\section{References}

1. AGRIQUEST. Malaysian Agricultural Directory \& Index 12th edition. Agriquest Sdn Bhd. (2009/2010)

2. K. Karhu, T. Mattila, I. Bergstrom, K. Regina, Ecosyst. Environ., 140, 13 (2011)

3. F.P. Vaccari, S. Baronti, E. Lugato, L. Genesio, S. Castaldi, F. Fornasier, F. Miglietta, Eur. J. Agron., 34, 231 (2011)

4. L.Y. Leng, M.H.A. Husni, A.W. Samsuri, Bioresource Technol., 102, 10759 (2011)

5. G.D. Clay, F. Worrall, CJ. Environ. Manage., 92, 675 (2011)

6. P.A. Jacinthe, C.D. Barton, S. Maharaj, Lal. Rattan, An evaluation of methodologies for assesing geogenic carbon in mine soils of the Eastern United States. In Soil Carbon Sequestration and the greenhouse effect, second edition, ed. R. Lal, R.F. Follett, 347363. Soil Science Society of America, Inc, USA (2009)

7. J. M. Bremner, D. R. Keeney, Anal. Chim. Acta., 32, 485 (1965) 
8. S. Olsen, C. Cole, F. Wanatable, L. Dean, Estimation of available phosphorus in soils by extraction with sodium bicarbonate. USDA Circular Nr 939, US Government Printing Office, Washington, D.C, United States (1954)

9. J. Muramoto, I. Goto, M. Ninaki, Jpn. J. Soil Sci. Plant. Nutr., 63, 210 (2009)

10. M.J. Antal, M. Gronli, Ind. Eng. Chem. Res., 42, 1619 (2003)

11. J.E. Amonette, S. Joseph. Characteristics of biochar: Micro-chemical properties. In Biochar for environmental management: Science and Technology, ed. J. Lehman and S. Joseph, Earthscan, London (2009)

12. S.M. Haefele, C. Knoblauch, M. Gummert, Y. Konboon, S. Koyama. Black carbon (biochar) in rice-based systems: characteristics and opportunities. Springer Science and Business Media B.V. (2009)

13. R.D. Geoffrey, L.T. Emma. Soil Microbiology and Sustainable Crop Production, Springer, New York (2010) 